University of Nebraska - Lincoln

DigitalCommons@University of Nebraska - Lincoln

Robert Katz Publications

Research Papers in Physics and Astronomy

August 1974

\title{
Cellular survival in a mixed radiation environment
}

Robert Katz

University of Nebraska-Lincoln, rkatz2@unl.edu

S. C. Sharma

University of Nebraska-Lincoln, sharma@uta.edu

Follow this and additional works at: https://digitalcommons.unl.edu/physicskatz

Part of the Physics Commons

Katz, Robert and Sharma, S. C., "Cellular survival in a mixed radiation environment" (1974). Robert Katz Publications. 81.

https://digitalcommons.unl.edu/physicskatz/81

This Article is brought to you for free and open access by the Research Papers in Physics and Astronomy at DigitalCommons@University of Nebraska - Lincoln. It has been accepted for inclusion in Robert Katz Publications by an authorized administrator of DigitalCommons@University of Nebraska - Lincoln. 
Published in International Journal of Radiation Biology 26:2 (August 1974), pp. 143-146;

doi 10.1080/09553007414551081 Published by Taylor \& Francis. Used by permission.

http://www.informaworld.com/smpp/content $\sim$ content $=\mathrm{a} 713854254 \sim \mathrm{db}=$ all $\sim$ order=page

Submitted December 4, 1973; accepted May 6, 1974.

\title{
Cellular survival in a mixed radiation environment
}

\author{
Robert Katz and S. C. Sharma \\ Behlen Laboratory of Physics, University of Nebraska-Lincoln, Lincoln, NE 68508, U.S.A.
}

\begin{abstract}
Calculations of the survival, r.b.e., and o.e.r. of human kidney cells, after sequential irradiation with gamma-rays and $14 \mathrm{MeV}$ neutrons, agree well with the experiments of Railton et al., with $\mathrm{CHO}$ cells in these radiation environments.

Les calculs de survie, de EBR et de FAO concernant les cellules du rein humain, après des séquences d'irradiation avec des rayons gamma et des neutrons $14 \mathrm{MeV}$, concordent bien avec les expériences de Railton et ses collègues sur des cellules $\mathrm{CHO}$ dans des milieux comportant les mêmes radiations.

Berechnungen des Überlebens, des RBW und des OER von menschlichen Nierenzellen nach aufeinanderfolgender Bestrahlung mit Gammastrahlen und $14 \mathrm{MeV}$ Neutronen stimmen gut überein mit Experimenten von Railton und anderen mit CHO Zeilen nach diesem Bestrahlungsmodus.
\end{abstract}

\section{Introduction}

Once cellular radiosensitivity parameters are evaluated experimentally, and the particle-energy spectrum of a radiation environment is known, the delta-ray theory of cellular survival (Katz, Ackerson, Homayoonfar, and Sharma 1971; Katz and Sharma 1974) provides an algorithm for finding the survival, as a function of dose, of the particular cell-line, in the particular ambience for which the parameters are evaluated. The theory has been used to good effect in calculating the survival of cells after irradiation with $14 \mathrm{MeV}$ neutrons (Katz and Sharma 1973), GeV nitrogen (Vosburgh 1971) and oxygen (Katz 1973) beams, and pion beams (Armstrong and Chandler 1974). Most recently it has been applied to calculating the survival of T. confusum eggs in the BEVALAC oxygen beam, after evaluating the radiosensitivity parameters from irradiation in HILAC beams (Katz 1973). Although all of these calculations implicitly involve "mixed radiation environments," a direct test of the ability of the theory to predict the survival of cells after a mixed radiation environment has recently been made possible by the research of Railton, Porter, Lawson, and Hannan (1974), who measured the survival, r.b.e., and o.e.r. of Chinese Hamster Ovary (CHO) cells after sequential irradiations with ${ }^{60}$ Co gamma-rays and D-T (14 $\mathrm{MeV}$ ) neutrons, in which the fraction, $\alpha$, of the total dose, delivered by gamma-rays, ranged from 0 to 1 . We apply the theory by making use of the spectrum of secondary charged particles from the interaction of $14 \mathrm{MeV}$ neutrons in tissue, from Caswell and Coyne (1972), and radiosensitivity parameters for human kidney cells evaluated from survival data obtained after irradiation with X-rays and heavy ion beams from the HILAC accelerator by Todd (1967).

\section{Methods and results}

In the absence of radiosensitivity parameters for $\mathrm{CHO}$ cells, we have based calculations on the parameters of T-1 human kidney cells, to find the surviving fraction, r.b.e., and o.e.r. in the mixed radiation environments of Railton et al. The choice of these parameters gives good agreement between theory and experiment, but the detailed agreement should be viewed as fortuitous, though the general trends and qualitative results from the theory are parameter independent. It is an unanticipated accident that the survival curves, r.b.e., and o.e.r. should be in remarkably good quantitative agreement with the data obtained with $\mathrm{CHO}$ cells. 
Following the algorithm of the theory (Katz and Sharma 1973), survival calculations are made at appropriate values of the dose $D$ and the fraction $\alpha$ of the total dose which is delivered as ${ }^{60}$ Co gammarays. We find the probability $\pi_{\mathrm{i}}$ for the survival of the irradiated cells in the ion-kill mode after irradiation with a dose $(1-\alpha) D$ of $14 \mathrm{MeV}$ neutrons, making use of the secondary particle spectrum in tissue from these neutrons. We then find the probability $\pi_{r}$ for survival in the gamma-kill mode after irradiation with a total gamma-kill dose consisting of the dose of ${ }^{60} \mathrm{Co}$ gamma-rays, and the fraction of the neutron dose delivered in the gamma-kill mode (from the theory). The surviving fraction of the cellular population is then the product of these two terms: $N / N_{0}=\pi_{\mathrm{i}} \times \pi_{\gamma}$. Though the calculation is complex in detail, requiring an integration over all the components of the secondary particle-energy spectrum from the neutron irradiation, it is perfectly straightforward in concept.

Calculated survival curves for aerobically-irradiated kidney cells are shown in Figure 1, for the values of $\alpha$ used experimentally (Railton et al. 1974). Experimental data are superimposed on the theoretical survival curves.

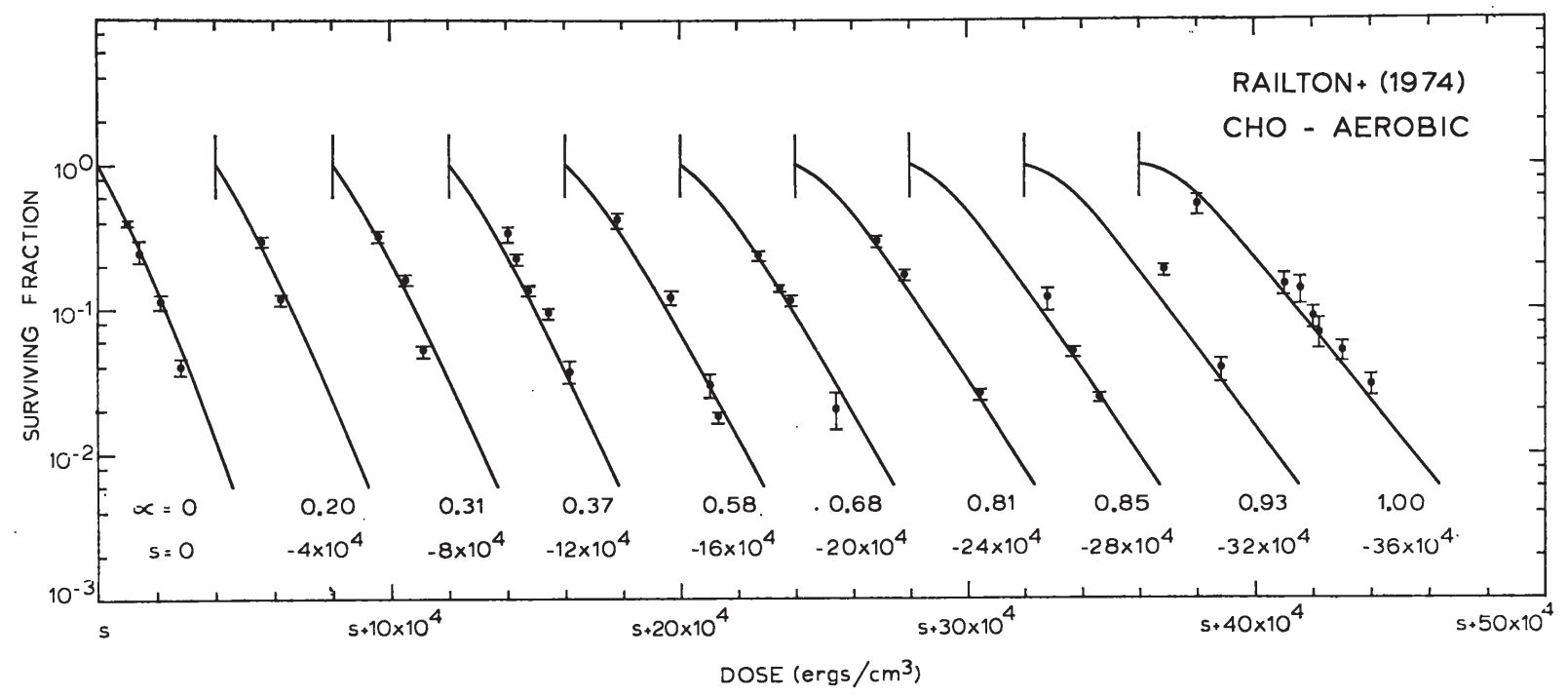

Figure 1. Calculated values of the surviving fraction of human kidney cells (plotted as curves), under aerobic conditions, as a function of the combined dose of ${ }^{60} \mathrm{Co}$ gamma-rays and $14 \mathrm{MeV}$ neutrons to which they are exposed. Here $\alpha$ is the fraction of the total dose delivered as gamma-rays, and $(1-\alpha)$ is the fraction delivered as neutrons. Measured values of the surviving fraction of CHO cells reported by Railton et al. (1974) in these environments are shown as points with error-bars.

Similar results are obtained for anoxically-irradiated cells. From the theoretical curves, the values of the r.b.e. of aerobically-irradiated kidney cells, at 10 per cent survival, are found, and plotted as a function of $\alpha$ in Figure 2. Experimental values of the r.b.e. are superimposed on these curves. The theoretical points are connected by a solid line. Departures from linearity become more pronounced at higher survival (lower dose) levels, also shown in Figure 2 as dashed lines. Calculated values of the o.e.r. for kidney cells are shown as a series of connected triangles in Figure 3. Superimposed on these curves are the experimental values obtained with $\mathrm{CHO}$ cells. Also shown in Figure 3, by a dashed line, is the rela- 


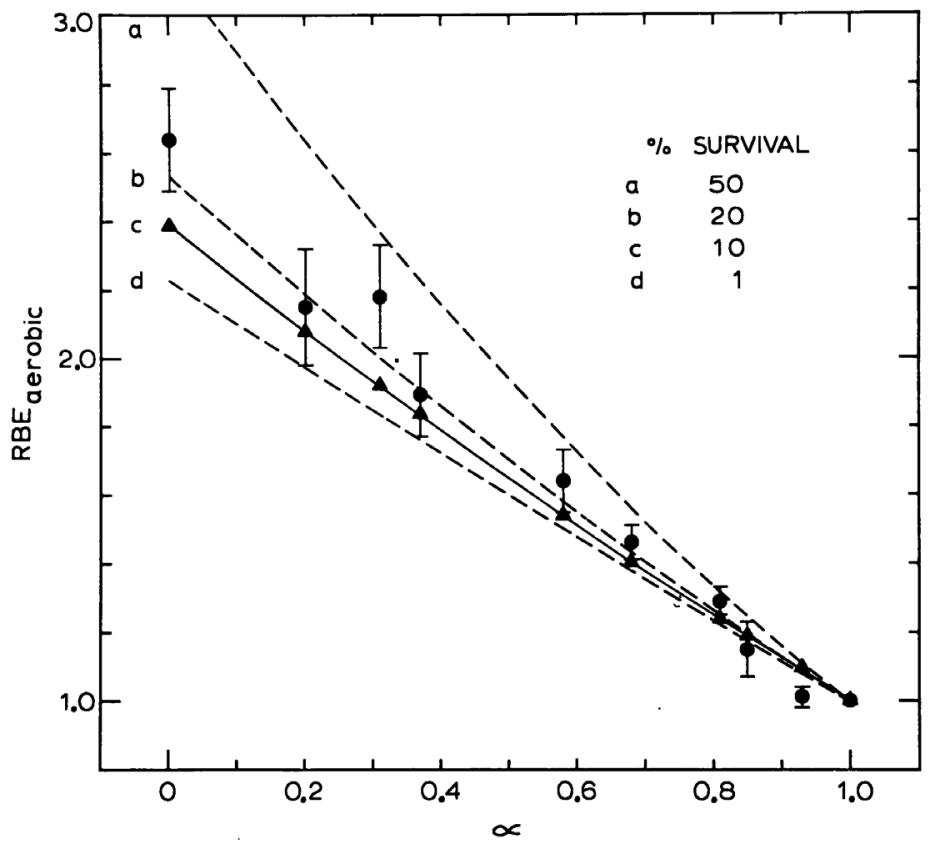

Figure 2. Calculated values of the r.b.e. (solid line at 10 per cent survival) of aerobically-irradiated human kidney cells are plotted as triangles, as a function of $\alpha$, with experimental values of the r.b.e. found for CHO cells plotted as circles with error- bars. Also shown, as dashed lines, are calculated values of the r.b.e. at other indicated survivals $(1,20$, and 50 per cent).

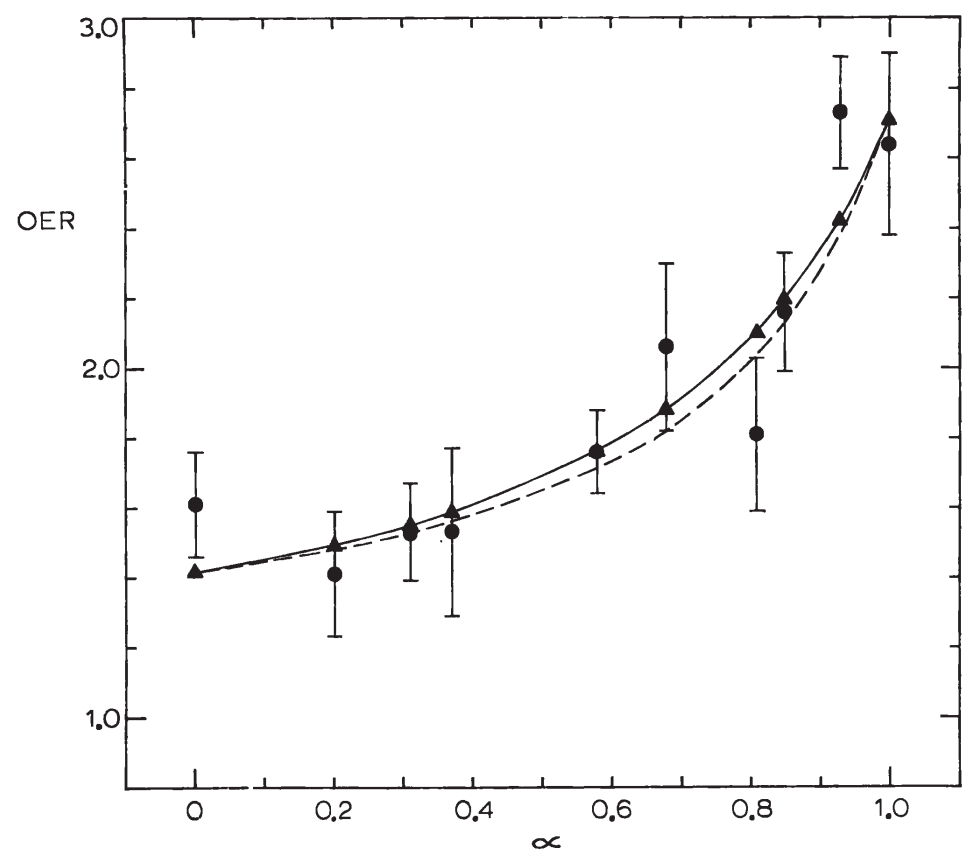

Figure 3. Calculated values of the o.e.r. (at 10 per cent survival) of human kidney cells are plotted as triangles, as a function of $\alpha$, with experimental values of the o.e.r. of $\mathrm{CHO}$ cells plotted as points with error-bars. The dashed line arises from the empirical formula of Hall. 
tionship between the o.e.r. and $\alpha$ for kidney cells, as calculated from an empirical formula proposed by Hall (Hall $1972 \mathrm{a} \& \mathrm{~b}$ ), where the o.e.r. in a mixed field, $\mathrm{O}_{\mathrm{m}^{\prime}}$ is given by

$$
\mathrm{O}_{\mathrm{m}}=\frac{\mathrm{O}_{\mathrm{n}} \mathrm{O}_{\gamma}\left(1+f_{\mathrm{n}}\left\{R_{\mathrm{n}}-1\right\}\right)}{\mathrm{O}_{\gamma} R_{\mathrm{n}} f_{\mathrm{n}}+\mathrm{O}_{\mathrm{n}}\left(1-f_{\mathrm{n}}\right)}
$$

where $\mathrm{O}_{\mathrm{n}}$ and $\mathrm{O}_{\gamma}$ are the o.e.r. values for neutrons and $\gamma$-rays, $f_{\mathrm{n}}$ is the fraction of the absorbed dose due to neutrons, and $R_{\mathrm{n}}$ is the r.b.e. of neutrons relative to $\gamma$-rays under aerated conditions. The numerical values used for the graph are $\mathrm{O}_{\mathrm{n}}=1.41, \mathrm{O}_{\gamma}=2.71, R_{\mathrm{n}}=2.39$, and are calculated (Katz and Sharma 1973) from the radiosensitivity parameters for kidney cells.

\section{Acknowledgments}

We thank Dr. David Porter for making these results available to us in advance of their publication, and for a stimulating exchange of letters. We thank Rose Ann Nelson for her help in the course of these investigations, and in the preparation of the manuscript for publication. This research is sponsored by the United States Atomic Energy Commission and the National Science Foundation (RANN).

\section{References}

Armstrong, T. W., and Chandler, K. C., 1974, Radiat. Res., 58, 293.

Caswell, R. S., and Coyne, J. J., 1972, Radiat. Res., 52, 448.

Hall, E. J., 1972 a, Br. J. Radiol., 45, 284; 1972 b, Ibid., 45, 628.

Katz, R., 1973, Round Table Conference: Heavy Ion Research in Radiological Physics and Radiation Chemistry with BEVALAC Ions, Berkeley (unpublished).

Katz, R., Ackerson, B., Homayoonfar, M., and Sharma, S. C., 1971, Radiat. Res., 47, 402.

Katz, R., and Sharma, S. C., 1973, Nucl. Instrum. Meth., 111, 93.

Railton, R., Porter, D., Lawson, R. C., and Hannan, W. J., 1974, Int. J. Radiat. Biol., 25, 121.

Todd, P., 1967, Radiat. Res. Suppl. 7, 196.

Vosburgh, K. G., 1971, Science, N.Y., 174, 1125. 